\title{
Exploring a Rural English Teacher's Lived Experiences of Assessment Practices in a Blended Learning Enactment: A Narrative Inquiry
}

\author{
Haris Sugianto \\ Correspondence: Haris Sugianto, Graduate Program in ELT, Universitas Islam Malang, Indonesia. \\ Received: September 9, 2021 \\ Accepted: November 22, 2021 \\ Online Published: November 23, 2021 \\ doi:10.5430/elr.v10n4p42 \\ URL: https://doi.org/10.5430/elr.v10n4p42
}

\begin{abstract}
Although a large number of studies have put a focus on the enactment of blended learning in English as a foreign language (EFL) classroom, there is a paucity of research into the teacher's lived experiences of how they enact assessment in the blended learning activities. To fill such a gap, this paper reports on a narrative inquiry of an EFL teacher's lived experiences of conducting assessment during blended learning in the pandemic era. The finding of the study shed light on the ineffectiveness of the assessment practice during the blended learning enactment, particularly in the context of rural schools. Albeit the participating teacher in this study was fully engaged to conduct assessment from his past experiences, two major problems hinder such a practice: students' unsubmitted assignments and poor Internet connection. Based on these findings, teachers are encouraged to find an alternative assessment practice during the blended learning, portfolio assessment can be an option. This suggestion is anchored by the fact that the assessment practice was not technically supported during the blended learning activities.
\end{abstract}

Keywords: assessment, blended learning, lived experience, narrative inquiry

\section{Introduction}

In recent years, the use of blended learning to provide course material to a diverse group of students is becoming more common in educational institutions. According to Castle and McGuire (2010), blended learning is widely used because of its potential to offer flexible access to information and teaching at any moment, from any place, and cost-effectiveness for institutions of higher education. Nowadays, impacted by coronavirus disease (COVID-19), many educational institutions in Indonesia are running blended learning. Such a learning approach combines the advantages of face-to-face and online learning to suit each individual which is a way of learning that is versatile, open and meaningful (Seffner \& Kepler, 2015). Blended learning focuses learner autonomy with utilizing information technology to build and facilitate positive learning (Quvanch \& Kew, 2020). According to Albiladi and Alshareef (2019), blended learning can also be easily applied to the four language skills. This subsequently engages learners to learn both virtually and face-to-face.

In the context of teaching, experience has an important element namely a full story of what someone experienced and what he did in the past as a teacher that provides insight into how experiences shape his knowledge and make decisions about assessment. According Lopez \& Vanegas (2020), experience refers to an event encountered by someone. Xu dan Liu (2009) stated that teacher's lived experiences in doing assessment shed light on the importance of conducting assessment for future learning activities. The insights teachers obtained in the previous experiences lead to an overview for the current assessment practice in the classes. An empirical study by Rasyidah et al. (2020) yields evidence that teachers' past experiences of assessment practice affect the way they carry out their present assessment practice.

Many previous studies have investigated and explored blended learning. Previous researchers have highlighted aspects of blended learning, for example Astria (2020) revealed that the application of blended learning is successful in the teaching and learning process and engages students in learning actively. Althomali and Alzeer (2020) showed in their study that blended learning can produce joyful learning activities for students as they participated in a variety of tasks. Alshareef (2019) contends that blended learning is appropriately enacted in teaching language skills. Recently, Dahmash (2020) revealed that blended learning has motivated EFL students to learn writing skills and encouraged them to look for resources online.

Given the many existing studies on blended learning, little empirical evidence is primarily focused on the aspect of assessment practice in blended learning enacted by English teachers, while assessment is part of the teaching and 
learning process which aims to improve the performance of the assessor and the person being assessed. As revealed by Black and Wiliam (2006) as cited in Khairil and Mokshein (2018), An assessment is a series of collecting all the tasks performed by a teacher on students. The assessment will be used as a reference in determining how the learning process will unfold. Recently, researchers have only focused on exploring assessments based on classroom learning, as has been done.

In particular, previous research focuses on the application and model of the assessment. For example, Zhank and Stock (2003) show that teachers rely more on objective classroom evaluation assessments and increased attention to evaluation consistency. Musawy (2009) contends that the main emphasis of current evaluation activities is on assessment, class discussions, class assignments, assignments, and seminars. It is thus essential to further explore teacher's lived experiences in conducting assessment during blended learning implementation.

Previous studies mentioned earlier in this paper were primarily carried out on face-to-face learning in the classroom and were also mostly conducted on teachers as participants at the university. There is a paucity of research that examines English as a foreign language teachers' lived experiences of assessment practice in blended learning in the schooling contexts. The present study looked into the lived experiences of an EFL teacher from a rural area in East Java, Indonesia, with regard to his assessment practice during the implementation of blended learning in the school.

\section{Method}

\section{Design}

To explore teacher's lived experiences, narrative inquiry was employed in this study. Narrative inquiry is the first and most important way to understand experiences. John Dewey's theory of experience, as cited from Clandinin and Connelly (2008) provides a foundation for attending to experience through three-dimensional space for narrative inquiry, namely the dimensions of continuity, place, and sociality. This three-dimensional space of narrative inquiry allows for investigation into the multilevel life experiences of researchers and participants. In this study, the stories that are told and lived are situated and understood in the larger cultural, social, and institutional narrative.

\section{Participant's Profile}

The participant in this study is Erick (pseudonym, male, 47 years old). My initial meeting with Erick began when he took his son to practice martial arts. Since that time. I often met and got acquainted with him. Erick is a senior English teacher at a secondary school based in Bangkalan regency, East Java, Indonesia with more than 25 years of teaching experiences. He obtained a Master's in English Education from a private university in Malang, East Java, Indonesia. Beside teaching in formal institution, Erick runs an English course in the afternoon after schooling time. Impacted by COVID-19 pandemic, Erick transformed his teaching from face-to-face to blended learning model in order to help his students engage in the online learning activities.

\section{Data Collection and Analysis Procedures}

Data in this study were collected through semi-structured interview. This interview design enables participant to voice their experiences without any restricted questions. The interview was done face-to-face using participant's national language by adhering to COVID-19 health protocols. It lasted around 45 minutes to an hour. Since the study was qualitatively conducted, the data obtained from the interview were analyzed following the qualitative framework for data analysis procedure. Initial process, I did interviews to collect stories and information from participant and then, I recorded it at the time of the interview into the mobile phone after that, I moved the data recorder into the folder in computer for analysis because data organization is very important in qualitative. And the further process, I listened the data recorder six times to transcript the data that has been got then, I read the interview transcripts five times to understand global meaning of the participant's stories. Further, several salient themes were highlighted in order to focus on the main issues related to the research questions. Afterward, the themes emerged from such a step were coded as the findings of the study. The I conducts member checking asking for feedback on whether the analyzed data is in accordance with what was conveyed by the participant.

\section{Findings}

Findings of this study are classified into two emerging themes: enacting blended learning in the teaching and learning process and navigating assessment during the teaching and learning process.

\section{Enacting blended learning: The source of teaching fulfillment}

Erick has been a teacher In Senior high school in bangkalan since 2003. At that school there are five English teachers, but only three teachers who teach English including him, and the other teachers teach Madura Language This is due to the fulfillment of the teaching hours of three English teachers who are already civil servants, each of whom must 
have twenty-four teaching hours in a week. Erick taught twelve classes consisting of tenth and eleventh grades. He always makes paper plan and analysis of basic competence and scope (linkage and integration between Based Competence, learning materials, learning models, learning activities, indicators of competency achievement, and assessment) but in practice, sometimes he gets out of the lesson plan that he had made. He conveyed:

\section{Excerpt 1}

Sometimes I teach in class out of the lesson plan that I already made because I adjust to the conditions of the class when I am teaching and also, I adjust what is needed in the class at that time.

At the beginning of the covid pandemic the learning process in his school used a full online course in accordance with the instructions of the education office. Erick used whatsapp groups in online learning practice. He made a voice recording to explain his materials, then he shared it in the group. If there was something not understood about his explanation, he asks students to send a private message or whatsapp group to ask the questions. He didn't use the zoom because there was no signal where his students lived

After a few months, He tried to apply online learning but, it did not run well and was ineffective because he found some problem in practicing online lerarning procces and he claimed full online learning will be possible if implemented in schools that are located in the city center. However, full online learning was not effective if applied in his school which is located in rural areas. It is depicted in his statement :

\section{Excerpt 2}

Since I taught in the school where is located in the rural, the students often complain about the unstable network in online learning, they also convey that their phone did not support by good aplplicatoion to open document who their teacher gave to them and sadly there were still students who don't have smartphone.

In addition, he also argued that online learning made him unable to recognize the character of his students because he did not interact directly in class. Online learning also had an effect on character building for students. When it came to online learning, students did not respect their teachers. This situation is reflected in Erick's statement. He shared:

\section{Excerpt 3}

I made a voice recording to explain my materials and shared some documents in the whatsapp group for them to learn and 1 said if there was not understood about my explanation, he ask students to send a private message or whatsapp group to ask the questions, and also I gave them some task and ask them to submit their task by sending it in whatsapp but 1 didn't get response from my students and they also didn't submit their task. I feel disrespected as a teacher

Therefore, based on the experience of online learning implementation, Erick has option to switch to apply blended learning, and then he conveys his ideas to his school with various problem that he found during online learning practice and his school agreed with his choice because the school realized that online learning is ineffective if applied continuously, Then, his school started to apply blended learning with students going to school alternately every week. He explained :

\section{Excerpt 4}

In the first week students with odd absences doing learning process with face-to-face learning in the school, while students who have even absences have to learn with online at home, and for the second week the students who have odd absences studied with online learning at home and students who have even absences came to school for study.

In blended learning practice, Erick used face-to-face learning to deliver learning materials, while for students who study at home he gives assignments to be done online as he has said :

\section{Excerpt 5}

During face-to-face learning at school I use it to deliver learning material, by delivering the material directly I feel more satisfied because there is direct interaction between me and students and I can also monitor my students. while for students who do online learning at home I give them assignments or practice questions to be done and then collected to me via online by whatsapp group.

He prefers to use whatsapp groups as a learning medium for students who study online at home. Besides, he gets 
advice from his friends. Whatsapp groups are an option because students are constrained by bad signals at student residences and also student cellphones that are not supported by good application when using other applications. He explained:

\section{Excerpt : 6}

After listening a story from my friend when studying with zoom, most students did not listen to the teacher's explanation and students did not want to turn on the video Throughout the process of learning and when students were immediately reprimanded immediately the students leaving the lesson, then students always complaining about unstable networks and cellphones that are not supported by adequate application features, finally I decided to do online learning through whatsapp groups, I think whatsapp is familiar to them and everyone can use it and also whatsapp does not require a high internet quota.

Then, the duration of learning process was also reduced, which originally one hour of the lesson had forty-five minutes and was changed to thirty minutes for one lesson. This reduction in teaching hours actually less effective because thirty minutes is very short time to explain the materials in learning process. It can be seen from the Erick's statement. He said:

\section{Excerpt 7}

Within 30 minutes I can't deliver all my material, it's too short, for example I want to explain about the simple past tense, but I haven't finished explaining my material but the time was up.

But, he still prefers to use blended learning in covid 19 pandemic rather than should be fully online at home. Because he said blended learning is more effective then online learning.

\section{Excerpt 8}

Blended learning is more effective than online learning. In online learning the students also never open or respond to learning videos or voice recordings that I submitted by online, by switching to blended learning, I hope the learning process will be more effective because we can do face-to-face learning activities even though not every day in one week but at least I can deliver lessons directly and can monitor and guide students directly.

\section{Enacting Assessment Practices}

In the past, before the pandemic, he was still doing face-to-face learning in the calss, he always explained the assessment procedures to his students. There are three aspects of the assessment that he used: knowledge, skills and attitudes. Because of the pandemic, he didn't explain it. He made an assessment that was not in accordance with the procedure. He explained that :

\section{Excerpt 9}

In the online learning practice students rarely joined online calss and submited assignments that I gave and many student scores were blank, If I follow the assessment procedures, then there will be many students whose get scores are below standard and they didn't complete in English lesson.

In blended learning practice Erick did face to face learning at school. He used it to explain his materials and recognize the character of students to conduct an attitude assessment, and for the students that were doing their learning process at home. He gave them task by online tests to conduct cognitive assessment. He told that:

\section{Excerpt 10}

During learningin the class, I can recognize the character of my students, I make observations to them about their behavior as an attitude assessment. Not only in class, I also pay attention to how often students respond and submit assignments to me because by responding and collecting assignments, it means students can appreciate a teacher, discipline and responsibility, it is also a factor in attitude assessment. Meanwhile, for cognitive assessment, I apply individual assessment by giving a test when students learn online at home despite the fact that many students did not submit their assignments.

He ever asked this students why they didn't submit assignments? Then, the same reason arose when online learning was implemented. They complained about the unstable network and also there are some students say they did not understand about the tasks but they were lazy and afraid to ask the teacher. He faces the same problem with online learning. He is confused about what strategy should he use to be able to overcome this problem and can assess the 
ability of students in English lessons properly. It is reflected in his statement:

\section{Excerpt 11}

1 confiuse how 1 will conducted asseessment to my students if my students rarely collected their task and 1 can't force them to collect their tasks because some reasons that they have ever said, then 1 decided to made an assessment by taking the assess in the previous semester for eleventh grades, and for tenth grades who just entered to school 1 gave a assess equivalent to minimum criteria competent. I feel sorry and afraid that if I give them a bad score, it will prevent them from continuing to higher school

His decision to give good grades to his students during the pandemic was teased by other teachers. She told that:

\section{Excerpt 12}

I was once insinuated by another teacher, he said to me "Mr. Erick, you have students who are very good in English, in English subject all students get good scores and no students are remedial while in other lessons many students get bad scores and remedies ".

The statement made him offended because he knew that the teacher meant to tease him but Erick didn't care about it. Because he had his own assessment of his students in the current condition of Covid 19.

On the other hand, he found that the student assignments that were submitted to him tended to be the same from one student to another so that there was an indication that they were cheating on the answers from their friends, and they did not do their own assignments. So it can be said that the current assessment is not purely the result of students' abilities, like what he said at the interview:

\section{Excerpt 13}

The student assignments submitted to me are almost all the same, I am sure they are working on the assignment together, not working on it alone. but I still appreciate their efforts by providing additional score.

The findings that appeared in the assessment process using the blended learning method made him focus on behavior assessment than on cognitive assessments. He said :

\section{Excerpt 14}

Cognitive scores is not really important because English is a science that can be learned later, it is not a measure of student success in the future but students' attitudes will determine their future because attitudes cannot be learned, but attitudes can be shaped and guided.

This incident reminded him of past events. He ever had a student with poor English language skills, so he got bad cognitive scores but he had a very good attitude and now he has good English language skills, in addition he is an English teacher. It needs the right strategy for this problem so that blended learning can be implemented in rural schools and teachers can carry out the assessment properly like what Erick expected. He expressed his wishes. He said

\section{Excerpt 15}

So far there is still no proper strategy for this problem, for now I think that the best solution is the learning process is carried out face-to-face in the classroom by complying with health protocols. Even if learning has to be done through blended learning, I think portfolio assessment is one of the right assessment methods.

\section{Discussion}

The assessments carried out by Erick used blended learning, influenced by his past experience when conducting assessments using online learning. This condition echoes previous research by Xu and Liu (2009) explaining that teacher's past experience of assessment practice greatly influence the present practice. Importantly, complexities he encountered during the assessment practice using blended learning were the same as in the online learning. Assessment is part of the teaching and learning process which is to improve the performance of the assessor and the person being assessed. According to Black and Wiliam (2006) as cited in Khairil and Mokshein (2018), An assessment is a series of collecting all tasks performed by a teacher to students then the assessment is used as a reference in determining how the learning process in the future should be enacted. In the present study, the participant referred back to the students' past assessment as a reference to assess the students' current competence in 
the class. Interestingly, this study reveals how the participant considers non-cognitive matters as the most essential assessment target. That is to say, students' character is seen important to support the learning process.

The personal and social circumstances are contributive to the participant's lived experiences. Feelings, hopes, desires, aesthetic responses, and spiritual dispositions are all examples of the personal conditions (Connelly \& Clandinin, 2006). In doing the assessment, Erick faced a dilemma. Such a practice is influenced by contextual conditions depicted in the interview. First, as an English teacher, the participant is responsible for assessing students' competence. However, this is hampered by the facts that student tasks were not completely submitted since, in some cases, many of the students were lacking an online facility. Thus, the only alternative carried out was to give a minimum assessment score for the students. Another dilemma is derived from collegial relationship in the teaching profession. As shared by the participant in the interview, his colleagues' negative responses were influential on the assessment practice. The present study uncovers a salient and common hindrance of assessment practice during blended learning in rural area schooling. As such, the interview data unpack how the participant was baffled with administering the assessment under inadequate facility and students' demotivation factor. Previous research confirmed this finding (Yan, Zhang, \& Fan, 2018).

\section{Conclusion}

The present study attempts to reveal an Indonesian English teacher's lived experiences of enacting assessment during the blended learning implementation. Findings suggest that conducting an assessment during the blended learning metod is less effective in rural schools. The primary concern in assessing students' learning activities in blended learning is the limited observation teachers do if compared to the classroom teachings. Although it is difficult to conduct assessment, blended learning is considered an effective teaching method for rural schools since the adoption of face-to-face and online activities enable both teachers and students to interact communicatively. From the findings, teachers are encouraged to find an alternative assessment practice during the blended learning, such as portfolio assessment.

\section{References}

Albiladi, W. S., \& Khlood, K. A. (2019). Blended learning in English teaching and learning: A review of the current literature. Journal of Language Teaching and Research, 10(2), 232-238. https://doi.org/10.17507/jltr.1002.03

Astria, H. (2020). Implementing blended learning to teach listening for university student. e-ISBN, 1(1), 194-201.

Bath, D., \& John, B. (2010). Getting started with blended learning. Grifth Institute for Higher Education, 24(2), $1-20$.

Castle, S. R., \& McGuire, C. J. (2010). An analysis of student self-assessment of online, blended, and face to face learning environments: Implication for sustainable education delivery. International Education Studies, 3(3), 36-40. https://doi.org/10.5539/ies.v3n3p36

Clandinin, D. (2006). Narrative inquiry: A methodology for studying lived experience. Research Studies in Music Education, 27(1), 44-54. https://doi.org/10.1177/1321103X060270010301

Clandinin, D. J.. \& Vera, C. (2008). Narrative Inquiry. In Lisa M. Given (Ed.), The Sage Encyclopedia of Qualitative Research Methods, 542-545.

Clandinin, D. J., Pushor, D., \& Murray, A. (2006). Navigating sites for narrative inquiry. Jounal of Teacher Education, 58, 21. https://doi.org/10.1177/0022487106296218

Creswell, J. W. (2012). Educational research : Planning, conducting, and evaluating quantitative and qualitative research. Library of Congress Cataloging-in-Publication Data. 4th ed.140-236.

Dahmash, N. B. (2020). 'I Couldn't Join the Session ': Benefits and challenges of blended learning amid covid-19 from EFL students. International Journal of English Linguistics, 10(1), 221. https://doi.org/10.5539/ijel.v10n5p221

Gulnaz, F., Amani, D. A. A., \& Daliyah, H. A. (2020). An investigation of the perceptions and experiences of the efl teachers and learners about the effectiveness of blended learning at Taif university. International Journal of English Linguistics, 10(1), 337-339. https://doi.org/10.5539/ijel.v10n1p329

Hill, K. (2017). Understanding classroom-based assessment practices: A precondition for teacher assessment literacy. Papers in Language Testing and Assessment, 6(1), 11-12.

Jeffrey, L. M., Milne, J., Suddaby, G., \& Higgins, A. (2012). Help or hindrance: Blended approaches and student engagement. Retrieved from Ako Aotearoa National Centre for Tertiary Teaching Excellence website 
http://akoaotearoa.ac.nz/download/ng/file/group-3089/help-or-hindrance-final-report.pdf

Khairil, L. F., \& Siti, E. M. (2018). 21st century assessment: Online assessment. International Journal of Academic Research in Business and Social Sciences, 8(1), 659-672. https://doi.org/10.6007/IJARBSS/v8-i1/3838

Lu, Y. H. (2005). Stories of teacher identity: A narrative inquiry into east asian ESL teachers' lives. Unpublished Dissertation. Retrieved in february 5, 2021 from https://drum.lib.umd.edu/handle/1903/3127

Mendieta, J., \& Gary, B. (2019). Blended language learning in the Colombian context: A narrative inquiry of teacher ownership of curriculum change. Computer Assisted Language Learning. 13-18. https://doi.org/10.1080/09588221.2018.1553888

Mussawy, S. A. J. (2009). Assessment practices: Student's and teachers' perceptions of classroom assessment. Master's Capstone Projects, 94-98.

Nguyen, X. N. C. M., \& Dao, P. (2019).Identity exploration and development in tesol teacher education: A three-dimensional space narrativeinquiry perspective. Tesol Journal, 10(4), 492. https://doi.org/10.1002/tesj.492

Quvanch, Z, \& Kew, S. N. (2020). A Review on impact of blended learning on the English writing skills. Innovative Teaching and Learning Journal, 4(1), 41-50.

Rasyidah, U., Triana, N., \& Saukah, A. (2020). The teachers' assessment knowledge and practice: Contribution of the past-time experiences to the present-time decision. The Qualitative Report, 25(7), 1738-1753. https://doi.org/10.46743/2160-3715/2020.4329

Suah, S. L., \& Saw, L. O. (2012). Investigating assessment practices of in-service teachers. International Online Journal of Educational Sciences, 4(1), 91-106.

Voogt, J., \& Roblin, N. P. (2012). A comparative analysis of international frameworks for 21st century competences: Implications for national curriculum policies. Journal of Curriculum Studies, 44(3), 299-321. https://doi.org/10.1080/00220272.2012.668938

Xu, Y., \& Yongcan, L. (2009). Teacher assessment knowledge and practice: A narrative inquiry of a Chinese college efl teacher's experience.Tesol Quarterly, 43(3), 493-512. https://doi.org/10.1002/j.1545-7249.2009.tb00246.x

Yan, X., Cong, Z., \& Jasom, J. F. (2018). Assessment knowledge is important, but ...”: How contextual and experiential factors mediate assessment practice and training needs of language teachers. Elsevier Ltd. All rights reserved, 74, 158-168. https://doi.org/10.1016/j.system.2018.03.003

Zhang, Z., \& Judith, A. B. S. (2010). Classroom assessment practices and teachers' Self-perceived assessment skills. Applied Measurement In Education, 16(4), 323-34. https://doi.org/10.1207/S15324818AME1604_4

\section{Copyrights}

Copyright for this article is retained by the author(s), with first publication rights granted to the journal.

This is an open-access article distributed under the terms and conditions of the Creative Commons Attribution license (http://creativecommons.org/licenses/by/4.0/). 